\title{
POTENSI PENCEMARAN DARI LIMBAH CAIR INDUSTRI PENGOLAHAN IKAN DI KECAMATAN MUNCAR, KABUPATEN BANYUWANGI
}

\author{
Oleh : Setiyono dan Satmoko Yudo \\ Peneliti di Pusat Teknologi Lingkungan, BPPT
}

\begin{abstract}
Fish processing industries in Muncar-Banyuwangi have increased the welfare of the people there and made this area known as the major fish producer in Indonesia. More than $50 \%$ of its production has been exported to many countries and the rest has fulfilled domestic need. Although fish processing industry has developed quickly, its industrial pollution effect hasn't been handled well so that it polluted the surrounding envionment especially water surface. It happened because of using water for industrial need reached $17.883,2 \mathrm{~m}^{3}$ /day and almost all industries haven't provided a good wastewater installalion so that the environment couldn't handle and neutrilize the wastes. This paper explains condition of fish processing industries and potential load of the wastewater produced by them.
\end{abstract}

Keywords : Industri Pengolahan Ikan, Limbah Cair Industri, Pencemaran Lingkungan, Informasi.

\section{PENDAHULUAN}

Industri pengolahan ikan di MuncarBanyuwangi telah berkembang sejak masa pendudukan Belanda. Pada awalnya Industri ini merupakan industri kecil, tetapi saat ini sebagian dari industri tersebut telah berkembang menjadi industri besar yang berorientasi ekspor. Industriindustri besar kondisinya cukup baik, dimana dalam melakukan proses produksi telah ditunjang dengan penggunaan peralatan modern, sementara sisanya masih merupakan industri kecil dengan peralatan dan proses produksi yang sederhana.

Industri pengolahan ikan di Muncar ini telah meningkatkan kesejahteraan masyarakat setempat dan telah memberikan peluang kerja yang cukup luas. Saat ini industri pengolahan ikan tersebut telah menjadi andalan dan ciri khas dari wilayah Banyuwangi.

Industri pengolahan ikan disamping memberikan peningkatan kesejahteraan dan pendapatan daerah, juga telah menimbulkan dampak negatif terhadap lingkungan sekitarnya. Salah satu dampak negatif yang telah menjadi sorotan masyarakat luas adalah timbulnya pencemaran terhadap lingkungan sekitarnya.

Rendahnya tingkat pemahaman IPAL dan sistem manajemen limbah menyebabkan sulitnya untuk mengelola limbah yang ada, sehingga hampir semua limbah yang dihasilkan di wilayah ini langsung dibuang ke saluran umum Pembuangan limbah secara langsung tanpa pengolahan ini menyebabkan tingginya tingkat pencemaran lingkungan di sekitar lokasi industri.
Tidak adanya sistem pengawasan penggunaan sumber daya air, maupun jumlah pembuangan limbah dari setiap perusahaan menyebabkan sulitnya dalam melakukan perencanaan pengelolaan limbah di lingkungan Muncar.

Jika kondisi ini tidak segera diwaspadai, dan permasalahan lingkungan tidak dikontrol secara ketat, maka berbagai dampak negatif akibat kegiatan ini akan semakin besar dan komplek sehingga untuk penanganannya memerlukan kerja keras dan perlu adanya kesadaran dari semua pihak untuk ikut andil dan berpartisipasi agar dapat segera menyelesaikan persoalan yang ada.

Untuk mengatasi permasalahan pengelolaan limbah di Muncar, sebagai langkah awal perlu diketahui berapa besar limbah dan jenis limbah yang dihasilkan oleh industri-industi yang ada di Muncar.

\section{TUJUAN DAN SASARAN}

Tujuan dari kegiatan ini adalah melakukan pendataan jumlah dan kapasitas industri pengolahan ikan di Muncar dan potensi timbulan limbah industri pengolahan ikan serta melakukan evaluasi dampak pencemaran lingkungan akibat industri pengolahan ikan.

Sasaran kegiatan ini adalah mengetahui potensi pencemaran lingkungan industri pengolahan ikan di Muncar sehingga pemecahan masalah pencemaran lingkungan dapat diatasi secara tepat dan cepat. 


\section{METODOLOGI}

Metodologi pelaksanaan kegiatan ini ada 3 tahap yaitu :

\section{Tahap Survai}

Survai kegiatan ini dilaksanakan di wilayah Muncar-Banyuwangi dengan melakukan observasi lapangan dan pendataan industri serta kapasitasnya. Juga dilakukan pendataan pemanfaatan sumberdaya oleh setiap industri.

\section{Tahap Pengumpulan Data}

Tahap ini merupakan pengumpulan data dengan melakukan survei :

1. Survai lokasi untuk mendapatkan data-data awal tentang :
a.Peta wilayah Kota Muncar.
b. Data jumlah industri.
c. Sebaran lokasi industri .

2. Survai kondisi industri untuk mendapatkan data-data :

a.Data kapasitas industri.

b. Data penggunaan sumber daya oleh setiap industri.

c. Data tentang jumlah dan karakteristik limbah

3. Survai kondisi lingkungan sekitar industri untuk mendapatkan data-data :

a. Dampak pembuangan limbah industri,

b. Tingkat pencemaran yang telah terjadi,

c. Dampak limbah terhadap kondisi sosial masyarakat sekitar

\section{Tahap Pengolahan Data dan Analisis}

Melakukan pengolahan data sekunder dan data primer dengan bantuan perangkat lunak basis data dan statistik kemudian hasilnya dianalisa dan dibahas.

\section{HASIL YANG DIHARAPKAN} adalah :

Hasil yang diharapkan dari pekerjaan ini

1. Diperolehnya data tentang jenis, jumlah dan kapasitas industri pengolahan ikan di Muncar.

2. Diperolehnya peta sebaran industri, kondisi lingkungan dan permasalahan lingkungan yang ada.

3. Diperolehnya data sebaran pembuangan limbah industri.
4. Diperolehnya gambaran tentang pengelolaan limbah di kawasan Muncar.

5. Hasil evaluasi dari kegiatan program ini yang mencakup informasi tentang potensi pencemaran akibat industri untuk dapat digunakan sebagai pendukung pengambilan keputusan dalam kebijakan pengelolaan lingkungan industri di kawasan Muncar.

\section{HASIL DAN PEMBAHASAN}

\subsection{Permasalahan Kawasan Muncar}

Dengan adanya pertumbuhan pesat industri-industri pengolahan ikan di kota Muncar telah memberikan potensi dampak yang sangat signifikan terhadap pertumbuhan kota tersebut yang akhirnya membawa berbagai pengaruh, baik yang bersifat positif maupun negatif. Beberapa pengaruh yang muncul antara lain:

- Peningkatan akan kebutuhan lahan baik peruntukan lahan untuk permukiman, kegiatan industri, perdagangan maupun kegiatan lainnya.

- Tidak terkendali dan tidak terarahnya pemanfaatan lahan sesuai RDTRK Muncar Tahun 1991/1992-2013/2015, terutama bangunan industri yang berada di luar peruntukan lahan industri dan berhimpitan dengan permukiman penduduk.

- Perkembangan pembangunan sarana dan prasarana perkotaan belum diimbangi dengan penyediaan utilitas perkotaan, antara lain :

- Dilihat dari fungsi sebagai pengendali banjir maupun sebagai tempat pembuangan limbah rumah tangga dan industri, sistem drainase yang ada belum terencana dg baik.

- Ditinjau dari segi peralatan, tenaga pengelola, TPS maupun TPA sistem pengelolaan sampah masih belum memadai.

- Industri pengolah ikan yang ada di Muncar sebagian besar belum dilengkapi dengan IPAL yang representatif karena keterbatasan lahan.

- Munculnya aktivitas masyarakat yang memanfaatkan limbah industri pengolahan ikan yang dibuang di selokan untuk bahan membuat minyak ikan.

5.1. Jenis dan Jumlah Kegiatan Usaha Pengolahan Ikan di Muncar 
Berbagai industri pengolahan ikan dalam skala industri besar, industri kecil maupun dalam skala industri rumah tangga telah berkembang dan sudah menjadi ciri khas daerah ini. Jenis industri pengolahan yang ada antara lain: industri minyak ikan, industri pengalengan ikan, industri pemindangan ikan, industri tepung ikan dan industri pengolahan ikan lainnya telah tumbuh di wilayah ini.

Sampai dengan tahun 2007, di wilayah Muncar telah tercatat ada sekitar 52 industri pengolahan ikan skala besar dan 39 industri pengolahan ikan skala kecil/rumah tangga. Secara detil daftar industri besar dan kecil serta jenis usahanya dapat dilihat pada Tabel 1 dan 2 sebagai berikut :

Tabel 1. Industri Pengolahan Ikan Skala Besar dan Jenis Usahanya Yang Terdaftar di Muncar

\begin{tabular}{|c|c|c|}
\hline NO. & NAMA INDUSTRI & JENIS USAHA \\
\hline 1. & PT. FKS Multi Agro, Tbk & $\begin{array}{l}\text { CS, Tepung dan } \\
\text { Minyak }\end{array}$ \\
\hline 2. & PT. FKS Multi Agro, Tbk & $\begin{array}{l}\text { CS, Tepung dan } \\
\text { Minyak }\end{array}$ \\
\hline 3. & PT. Maya Muncar & $\begin{array}{l}\text { CS, dan } \\
\text { Pengalengan }\end{array}$ \\
\hline 4. & PT. Blambangan Raya & $\begin{array}{l}\text { CS, Tepung dan } \\
\text { Pengalengan }\end{array}$ \\
\hline 5. & PT. Blambangan Raya & $\begin{array}{l}\text { Tepung dan } \\
\text { Pengalengan }\end{array}$ \\
\hline 6. & $\begin{array}{l}\text { PT. Sumber Yala } \\
\text { Samudera }\end{array}$ & $\begin{array}{l}\text { CS, Tepung dan } \\
\text { Pengalengan }\end{array}$ \\
\hline 7. & CV. Sari Laut Jaya Lestari & $\begin{array}{l}\text { Tepung dan } \\
\text { Pengalengan }\end{array}$ \\
\hline 8. & CV Sari Laut JL & $\begin{array}{l}\text { Tepung dan } \\
\text { Pengalengan }\end{array}$ \\
\hline 9. & $\begin{array}{l}\text { PT. Avila Prima Intra } \\
\text { Makmur }\end{array}$ & $\begin{array}{l}\text { CS, Tepung dan } \\
\text { Pengalengan }\end{array}$ \\
\hline 10. & CV. Manunggal Prima & Cold Storage \\
\hline 11. & UD. Indra Lasmana & Cold Storage \\
\hline 12. & UD. Giat & Cold Storage \\
\hline 13. & UD. Giat & Cold Storage \\
\hline 14. & UD Rahayu Jaya & Cold Storage \\
\hline 15. & NV Muncar & Pengalengan \\
\hline 16. & PT. Sari Laut Jaya Lestari & Tepung \\
\hline 17. & $\begin{array}{l}\text { CV. Surya Blambangan } \\
\text { Kencana }\end{array}$ & Pengalengan \\
\hline 18. & $\begin{array}{l}\text { UD. Maju Jaya/UD. Putra } \\
\text { Bangsawan }\end{array}$ & Cold Storage \\
\hline 19. & UD. Piala Indah & Cold Storage \\
\hline 20. & UD. Mayang Jaya & Cold Storage \\
\hline
\end{tabular}

\begin{tabular}{|c|c|c|}
\hline 21. & UD. Putra Barokah & Cold Storage \\
\hline 22. & $\begin{array}{l}\text { PT. Prima Lautan } \\
\text { Indonesia }\end{array}$ & Tepung \\
\hline 23. & UD. Aneka Pangan & CS dan Tepung \\
\hline 24. & CV. Sumber Cahaya & Cold Storage \\
\hline 25. & CV. Karunia & Cold Storage \\
\hline 26. & UD. Savina & $\begin{array}{l}\text { Cold Storage \& } \\
\text { Supplier F }\end{array}$ \\
\hline 27. & UD. Perdana & Cold Storage \\
\hline 28. & CV. Pasific Harvest & $\begin{array}{l}\text { Cold Storage \& } \\
\text { Pengalengan }\end{array}$ \\
\hline 29. & CV. Pasific Harvest & $\begin{array}{l}\text { Cold Storage \& } \\
\text { Pengalengan }\end{array}$ \\
\hline 30. & UD. Selat Bali & Cold Storage \\
\hline 31. & $\begin{array}{l}\text { UD. Sinar Mas Mina } \\
\text { Bahari }\end{array}$ & Cold Storage \\
\hline 32. & UD. Kembar Jaya & Cold Storage \\
\hline 33. & NV Muncar II & Cold Storage \\
\hline 34. & PT. Sari Feed Indojaya & Pakan Udang \\
\hline 35. & UD. Sumber Protein & Tepung \\
\hline 36. & UD. Mulia Bahari & Cold Storage \\
\hline 37. & $\begin{array}{l}\text { CV. Surya Jaya/Putra } \\
\text { Samudera Tunggal Jaya }\end{array}$ & Tepung \\
\hline 38. & CV. Sumber Asia & Tepung \\
\hline 39. & PT. Unggul Inti Samudera & Tepung \\
\hline 40. & $\begin{array}{l}\text { PT. Karya Manunggal } \\
\text { Prima Sukses }\end{array}$ & Pengalengan \\
\hline 41. & Air Buana & Tepung \\
\hline 42. & UD. Sinar Tratas & Tepung \\
\hline 43. & UD. Sinar Tratas & Tepung \\
\hline 44. & CV. Pasific Harvest & Tepung (rencana) \\
\hline 45. & Perorangan: Haji Sadli & Tepung \\
\hline 46. & UD. Sari Cahaya Laut & Cold Storage \\
\hline 47. & UD. Intan Laut & Tepung \\
\hline 48. & $\begin{array}{l}\text { UD. Sumber Laut } \\
\text { Sekawan }\end{array}$ & Tepung \\
\hline 49. & PT. Indo Sari Laut & Tepung \\
\hline 50. & CV. Biji Sesawi & Tepung \& Minyak \\
\hline 51. & UD. Sumber Murni & Tepung \\
\hline
\end{tabular}




\begin{tabular}{|r|l|l|}
\hline 52. & CV. Pasific Harvest & $\begin{array}{l}\text { Tepung dan } \\
\text { Pengalengan }\end{array}$ \\
\hline
\end{tabular}
Sumber:

Laporan Pengelolaan Lingkungan Industri Pengolahan Ikan di Muncar. Kedeputian Bidang Pengendalian Pencemaran Lingkungan, KLH. 2007.

Tabel 2. Daftar Usaha Dan Pemilik Usaha Kecil Rumah Tangga Dan Jenis Usahanya Di Wilayah Muncar

\begin{tabular}{|c|c|c|c|c|}
\hline NO & $\begin{array}{c}\text { NAMA } \\
\text { PEMILIK }\end{array}$ & JENIS USAHA & $\begin{array}{l}\text { KAP } \\
\text { PRO }\end{array}$ & $\begin{array}{l}\text { TAS } \\
\text { KSI }\end{array}$ \\
\hline 1. & Aman & $\begin{array}{l}\text { - Tepung Ikan } \\
\text { - } \quad \text { Petis Udang }\end{array}$ & $\begin{array}{c}10 \\
300\end{array}$ & $\begin{array}{l}\text { ton } \\
\mathrm{kg}\end{array}$ \\
\hline 2. & Bakri & Tepung Ikan & 10 & ton \\
\hline 3. & H. Samsi & Tepung Ikan & 10 & ton \\
\hline 4. & Juwairi & Tepung Ikan & 10 & ton \\
\hline 5. & Misrawi & Tepung Ikan & 10 & ton \\
\hline 6. & Sudali & Tepung Ikan & 10 & ton \\
\hline 7. & Taslim Tas & Tepung Ikan & 10 & ton \\
\hline 8. & Tasmi H. & Tepung Ikan & 10 & ton \\
\hline 9. & Abdullah & Minyak Ikan & 600 & liter \\
\hline 10. & Hernadi & $\begin{array}{l}\text { Minyak Ikan } \\
\text { (Penampungan) }\end{array}$ & 5.000 & liter \\
\hline 11. & Hernadi Cs. & Minyak Ikan & 5.000 & liter \\
\hline 12. & Mistia Cs & Minyak Ikan & 3.400 & liter \\
\hline 13. & NN Cs & Minyak Ikan & & liter \\
\hline 14. & Ponisa Cs & Minyak Ikan & 800 & liter \\
\hline 15. & Sai Cs & Minyak Ikan & 400 & liter \\
\hline 16. & Sukarmin & Minyak Ikan & 800 & liter \\
\hline 17. & Suratih & Minyak Ikan & 2.000 & liter \\
\hline 18. & Susarimi & Minyak Ikan & 1.200 & liter \\
\hline 19. & Susarimin & $\begin{array}{l}\text { Minyak Ikan } \\
\text { (Penampungan) }\end{array}$ & 1.200 & liter \\
\hline 20. & Yahya & Minyak Ikan & 3.000 & liter \\
\hline 21. & Asnawi & $\begin{array}{l}\text { Pemindangan } \\
\text { Ikan }\end{array}$ & $\mathrm{tt}$ & ton \\
\hline 22. & $\begin{array}{l}\text { Juned (Biduri } \\
\text { Laut) }\end{array}$ & Lainnya & $\mathrm{tt}$ & ton \\
\hline 23. & Giyono & Lainnya & $\mathrm{tt}$ & ton \\
\hline 24. & H. Ridhoi & Lainnya & $\mathrm{tt}$ & ton \\
\hline 25. & H. Sahri & Lainnya & $\mathrm{tt}$ & ton \\
\hline 26. & H. Sair & Lainnya & $\mathrm{tt}$ & ton \\
\hline 27. & $\begin{array}{l}\mathrm{H} . \\
\text { Sholahuddin }\end{array}$ & Lainnya & $\mathrm{tt}$ & ton \\
\hline 28. & H. Sulton & Lainnya & $\mathrm{tt}$ & ton \\
\hline 29. & Hariri & Lainnya & $\mathrm{tt}$ & ton \\
\hline 30. & Hasan & Lainnya & $\mathrm{tt}$ & ton \\
\hline 31. & Husen & Lainnya & $\mathrm{tt}$ & ton \\
\hline 32. & Ismail & Lainnya & $\mathrm{tt}$ & ton \\
\hline 33. & Mustari & Lainnya & $\mathrm{tt}$ & ton \\
\hline
\end{tabular}

\begin{tabular}{|c|l|l|c|c|}
\hline 34. & Mustofa & Lainnya & $\mathrm{tt}$ & ton \\
\hline 35. & Saiful & Lainnya & $\mathrm{tt}$ & ton \\
\hline 36. & Samsul & Lainnya & $\mathrm{tt}$ & ton \\
\hline 37. & Sefi'i & Lainnya & $\mathrm{tt}$ & ton \\
\hline 38. & $\begin{array}{l}\text { UD. Indra } \\
\text { Laksana } \\
\text { (H.A) }\end{array}$ & Lainnya & $\mathrm{tt}$ & ton \\
\hline 39. & Zainudin & Lainnya & $\mathrm{tt}$ & ton \\
\hline
\end{tabular}

Lainnya : Jenis produk tidak tetap bergantung musim, $T t$ : tidak tetap

\subsection{Sebaran Industri Pengolahan Ikan di Muncar}

Sebaran lokasi industri pengolahan ikan di Muncar ini meliputi 3 desa yaitu : Desa Tembokrejo, Kedungrejo dan Blambangan. Secara detail peta sebaran industri pengolahan ikan yang ada dapat dilihat pada Gambar 3 dalam lampiran.

Di kawasan Muncar tidak tersedia sarana pengelolaan limbah skala kawasan, sehingga semua limbah di buang menggunakan sarana drainase air hujan yang ada dan langsung ke sungai terdekat atau laut. Titik-titik pembuangan limbah ini juga tersebar dan tidak terkontrol, sehingga semakin menyulitkan dalam pemantauan kualitas lingkungan.

\subsection{Kapasitas Produksi Pengolahan Ikan}

Berdasarkan hasil survai dan pedekatan penghitungan kapasitas produksi dari 52 industri pengolahan ikan skala besar dan menengah, maka total kapasitas produksi per-harinya adalah 1.209 ton/hari. Sedangkan untuk penghitungan kapasitas produksi dari 39 industri pengolahan ikan skala kecil/rumah tangga, maka rata-rata produksi per harinya adalah 203,4 ton.

Tabel 3. Kapasitas Produksi Pengolahan Ikan di Muncar

\begin{tabular}{|l|l|c|}
\hline No. & \multicolumn{1}{|c|}{ Industri Skala Besar } & Ton/hari \\
\hline 1. & Pengalengan Ikan & 145 \\
\hline 2. & Tepung Ikan & 505 \\
\hline 3. & Cold Storage Ikan & 210 \\
\hline 4. & Minyak Ikan & 29 \\
\hline 5. & Pengolahan Ikan Lainnya & 320 \\
\hline & & \\
\hline No. & Industri Skala Kecil/Mngh & Ton/hari \\
\hline 1 & Tepung ikan & 80 \\
\hline 2 & Minyak ikan & 23,4 \\
\hline 3 & Pemindangan ikan & 100 \\
\hline
\end{tabular}

Sumber:

Laporan Pengelolaan Lingkungan Industri Pengolahan

Ikan di Muncar. Kedeputian Bidang Pengendalian

Pencemaran Lingkungan, KLH. 2007. 


\subsection{Kebutuhan Bahan Baku}

Bahan baku yang digunakan untuk setiap usaha pengolahan ikan juga tergantung dari jenis produksinya. Sebagian industri menggunakan bahan baku dari buangan ikan industri lainnya, seperti industri tepung ikan banyak menggunakan potongan ikan dan isi perut ikan dari perusahaan pengalengan ikan untuk diproses menjadi tepung ikan. Begitu juga untuk industri minyak ikan, banyak menggunakan ikan buangan dari perusahaan lain. Dengan demikian maka untuk menghitung penyerapan bahan baku ikan ini dilakukan pendekatan-pendekatan sesuai dengan jenis kegiatan yang ada berdasarkan hasil survai dan diskusi dengan para pengusaha setempat.

Pendekatan pemakaian sumber daya ikan laut untuk industri pengolahan ikan adalah sebagai berikut:

- Industri pengalengan ikan :

Jumlah produk = jumlah bahan baku,

- Industri tepung ikan:

Jumlah produk $=30 \%$ jumlah bahan baku,

- Industri cold storage ikan :

Jumlah produk = jumlah bahan baku,

- Industri minyak ikan :

Jumlah produk $=7 \%$ jumlah bahan baku,

- Industri pengolahan ikan lainnya :

Jumlah produk = jumlah bahan baku.

Dengan menggunakan asumsi seperti tersebut, maka jumlah penyerapan ikan dapat dihitung, dan total kebutuhan bahan baku (ikan laut) untuk 69 perusahaan pengolahan ikan tersebut adalah $1.438,5$ ton/hari.

\subsection{Kondisi Industri di Muncar}

Kondisi setiap industri pengolahan ikan di Muncar tidak sama. Sebagian industri telah berkembang dengan teknologi modern dan hasilnya telah dapat menembus pasar ekspor, namun sebagian industri kondisinya masih sangat memprihatinkan, yaitu dilaksanakan dengan cara-cara tradisional dan bahkan ada yang dikerjakan dengan kondisi yang kurang sehat, baik dilihat dari proses produksinya maupun dari lingkungan kerjanya. Sebagian besar industri kecil yang ada dalam kondisi demikian.

Kondisi kegiatan dan produk industri di Muncar ini dapat dilihat seperti pada Foto-foto 1 s.d. 6 sebagai berikut :

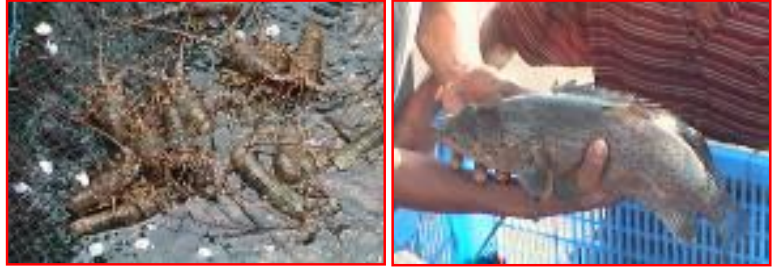

Foto 1. Hasil Perikanan Laut Di Perairan Muncar
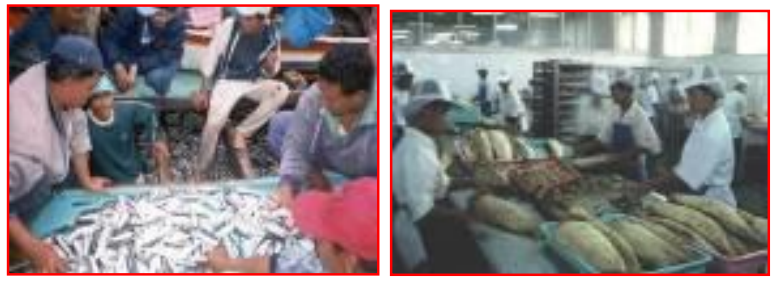

Foto 2. Kegiatan Pelelangan Ikan Laut Di Muncar
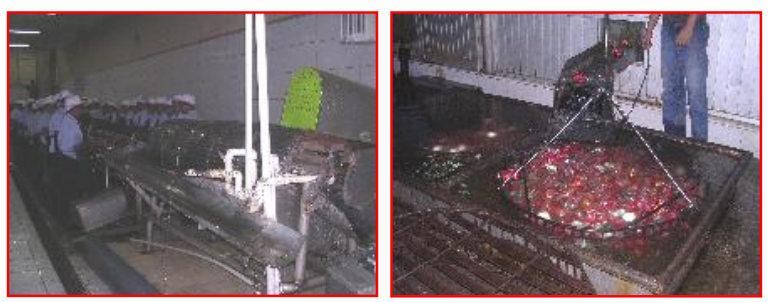

Foto 3. Proses Produksi Pengolahan Ikan
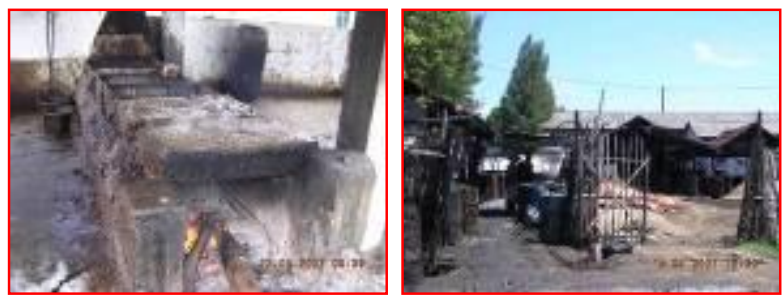

Foto 4. Proses Produksi Dan Kondisi Industri Kecil Di Muncar
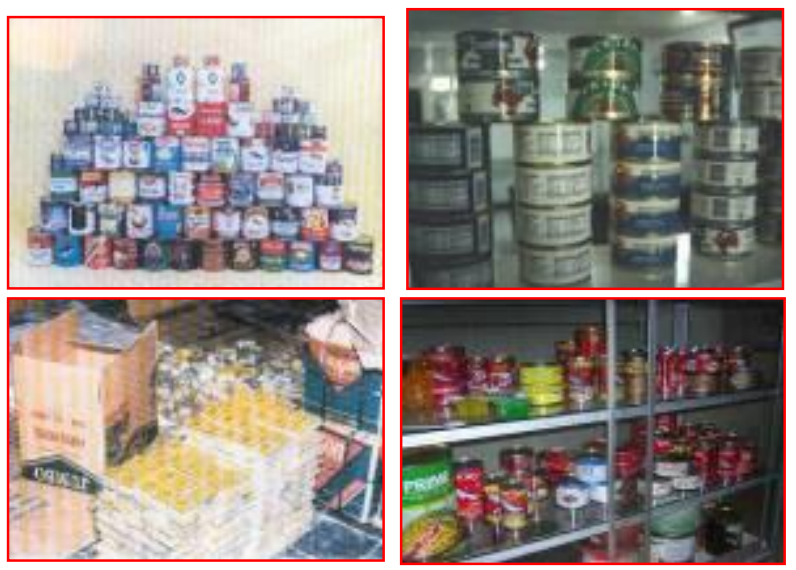

Foto 5. Contoh Produk Industri Besar Di Muncar

Kondisi industri kecil yang masih sangat memerlukan uluran tangan dari semua pihak untuk peningkatan produktivitasnya di Muncar ini 
dapat dilihat seperti pada foto-foto kegiatan sebagai berikut :
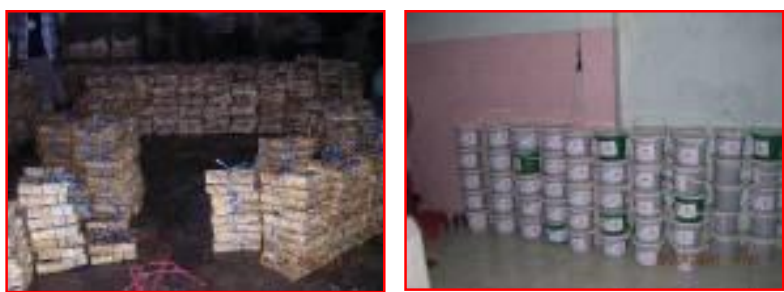

Foto 6. Contoh Produk Hasil Pengolahan Ikan Industri Kecil Di Muncar

\subsection{Potensi Sumber Pencemaran / Sumber Limbah}

Pencemaran yang ditimbulkan dari industri pengolahan ikan berasal dari beberapa sumber, mulai dari transportasi bahan baku, pemindahan bahan baku, pencucian bahan, proses produksi, kegiatan laboratorium (quality control), aktivitas karyawan (limbah domestik) dan lain-lain. Dari hasil survai diketahui bahwa potensi sumber limbah industri pengolahan ikan mulai ada sejak kegiatan pendaratan ikan, transportasi ikan, pencucian bahan baku, proses produksi, sampai sarana pengolahan limbah yang kurang berfungsi dengan baik. Secara detail potensi sumbersumber limbah ini dapat dilihat seperti pada Foto 7 s.d. 11.
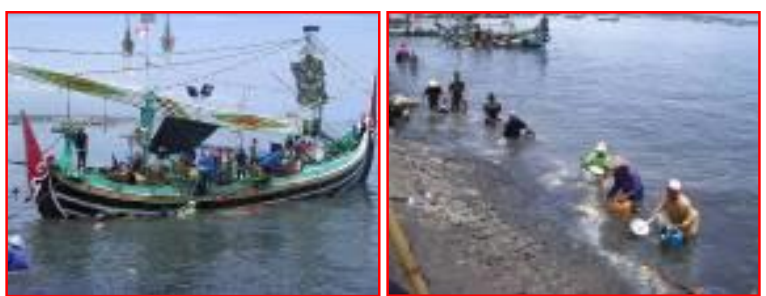

Foto 7. Kegiatan Pendaratan Ikan Di Pelabuhan
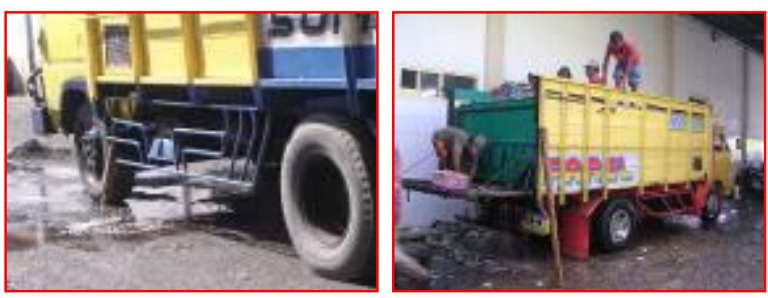

Foto 8. Kegiatan Transportasi lkan
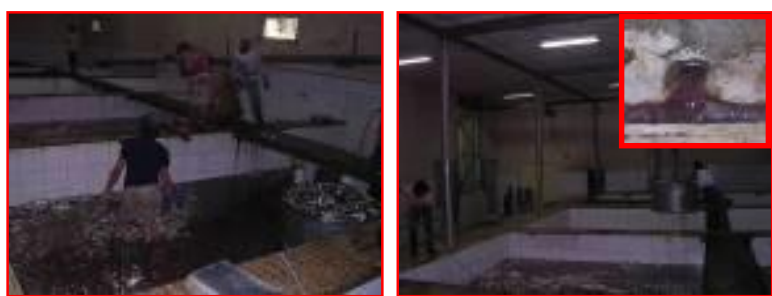

Foto 9. Kegiatan Pencucian Bahan Baku
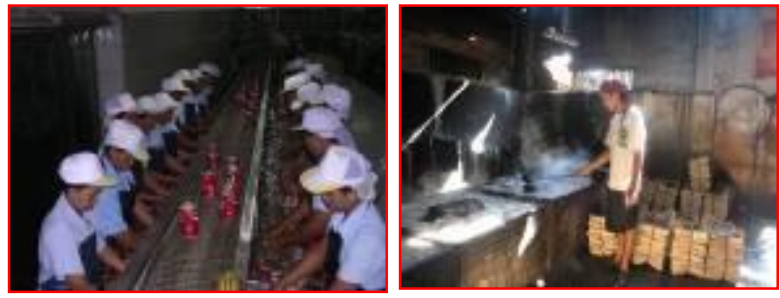

Foto 10. Kegiatan Proses Produksi
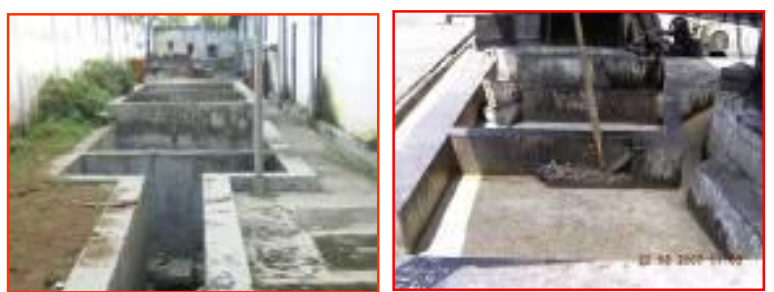

Foto 11. Fasilitas Pengolahan Limbah Yang Tidak Dapat Berfungsi Dengan Baik

\subsection{Potensi Jumlah Limbah Yang Dihasilkan}

Berdasarkan sumbernya, air limbah yang dihasilkan di kawasan industri pengolahan ikan ini dikelompokkan atas 2 jenis, yaitu:

1. Air limbah domestik, yaitu air limbah yang berasal dari kamar mandi, toilet, kantin, wastavel dan tempat wudu. Sesuai dengan aktivitasnya, maka sumber air limbah domestik ini dihasilkan oleh semua industri yang ada.

2. Air limbah produksi, berasal dari aktivitas produksi seperti pencucian komponenkomponen peralatan dan lantai ruang produksi. Sesuai dengan jenis kegiatannya/ industrinya dan aktivitas yang ada di setiap perusahaan, maka air limbah ini dapat dikelompokkan dalam beberapa kelompok dengan karakteristik yang berlainan, yaitu air limbah industri tepung ikan, air limbah industri minyak ikan, air limbah industri cold storage, dan air limbah industri pengalengan ikan.

Dalam proses produksi, air digunakan mulai dari pencucian/pembersihan bahan baku, pembersihan isi perut ikan, pemasakan, dan pembersihan lokasi pabrik. Karena sampai saat ini sistem monitoring/kontrol terhadap kebutuhan air di Muncar belum baik, maka untuk menghitung jumlah pemakaiannya dilakukan pendekatan-pendekatan sesuai dengan jenis kegiatan yang ada berdasarkan hasil survai dan diskusi dengan para pengusaha setempat.

Pendekatan/asumsi pemakaian sumber daya air untuk industri pengolahan ikan skala besar adalah sebagai berikut: 
- Industri pengalengan ikan $=20 \mathrm{~m}^{3} /$ ton produk.

- Industri tepung ikan $=12 \mathrm{~m}^{3} /$ ton produk.

- Industri cold storage ikan $=15 \mathrm{~m}^{3} /$ ton produk.

- Industri minyak ikan $=10 \mathrm{~m}^{3} /$ ton produk.

- Industri pengolahan ikan lainnya $=15 \mathrm{~m}^{3} / \mathrm{ton}$ produk.

- Keperluan domestik =0,10 $\mathrm{m}^{3}$ /orang.hari.

Catatan :

(Asumsi kebutuhan air ini berdasarkan kebutuhan air maksimal yang diijinkan menurut Peraturan Menteri LH. No. 06 tahun 2007, tentang Baku Mutu Air Limbah Bagi Usaha dan/ atau Kegiatan Pengolahan Hasil Perikanan).

Dengan menggunakan asumsi seperti tersebut, maka jumlah kebutuhan air bersih untuk industri skala besar di Muncar rata-rata $14 \mathrm{~m}^{3} /$ ton produk. Dengan demikian maka kebutuhan air secara total adalah ${ }^{1)}$ :

- Kebutuhan air produksi $=17.358,5 \mathrm{~m}^{3} /$ hari,

- Kebutuhan domestik $=474,7 \mathrm{~m}^{3} /$ hari.

Total kebutuhan air bersih $=17.833,2 \mathrm{~m}^{3}$ perhari.

Besarnya jumlah pemakaian air untuk kegiatan industri ini, berarti juga akan dihasilkan limbah cair yang sangat besar pula. Pada umumnya perhitungan jumlah limbah adalah $80 \%$ dari jumlah pemakaian air bersih yang ada. Berdasarkan pendekatan tersebut, maka jumlah limbah cair yang dihasilkan dapat mencapai $14.266 \mathrm{~m}^{3} /$ hari.

\subsection{Peta Sebaran Limbah}

Air limbah domestik, yang berasal dari kamar mandi dibuang secara langsung ke saluran umum bercampur dengan air limbah dari kantin, wastavel dan tempat wudu. Saluran pembuangan limbah ini juga masih menyatu dengan air limbah produksi. Air limbah domestik yang berasal dari toilet, di olah dengan septic tank dan menggunakan teknik resapan.

Beberapa perusahaan telah melakukan penanganan limbah industrinya, namun upaya yang dilakukan masih sangat sederhana. Penanganan yang telah ada hanya berupa oil trap dan beberapa bak pengendap sederhana saja. Di beberapa perusahaan telah berusaha membuat instalasi pengolahan limbah, namun instalasi-instalasi tersebut tidak ada yang befungsi dengan baik. Minimnya penanganan limbah di dalam lingkungan perusahaan, menyebabkan masih banyak kandungan minyak dan kotoran (serpihan ikan dan sisik ikan) yang terikut dalam aliran limbah. Secara detail sistem pengelolaan limbah di dalam lingkungan perusahaan, di kawasan Muncar dapat dilihat pada Gambar 12.

Lokasi industri pengolahan ikan di Muncar ini tumbuh secara alami di suatu kawasan yang tidak dipersiapkan secara khusus sebagai kawasan industri. Karena tidak adanya perencanaan kawasan secara khusus, maka keberadaan industrinya menyebar ke seluruh kawasan Muncar.

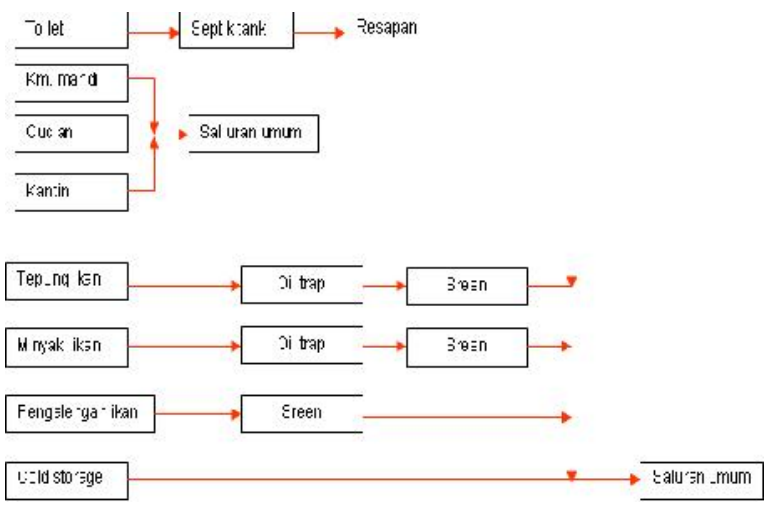

Gambar 12. Sistem Pengelolaan Limbah Industri di Muncar

Dengan kondisi yang demikian, maka sumber limbah yang dihasilkan juga menyebar sesuai dengan penyebaran lokasi industrinya. Limbah industri di kawasan ini belum dikelola secara khusus, sehingga semua limbah akan disalurkan mengikuti sistem drainase yang ada atau langsung disalurkan ke sungai atau laut sesuai dengan keberadaan industri dan kondisi lingkungan yang termudah untuk menyalurkan limbah. Secara detail penyebaran lokasi sumber limbah dan sistem jaringan limbah di kawasan Muncar ini dapat dilihat seperti pada Gambar 3 dan 4 pada lampiran.

\subsection{Dampak Dari Pembuangan Limbah}

Kegiatan industri di Muncar telah menimbulkan perubahan terhadap kondisi lingkungan di sekitarnya yang tidak mungkin untuk dihindari. Perubahan yang terjadi dapat bersifat positif dan bersifat negatif. Perubahan positif, seperti terbukanya lapangan kerja baru, peningkatan kesejahteraan masyarakat, meningkatnya pendapatan daerah, ber kembangnya wilayah kota dan lain-lain, harus dijaga dan ditingkatkan agar dapat memberikan manfaat yang sebesar-besarnya. Sedangkan perubahan yang bersifat negatif, seperti adanya pencemaran terhadap lingkungan, meningkatnya kebutuhan lahan yang kurang terkendali dan lainlain, harus dikendalikan agar tidak menimbulkan kerugian. 


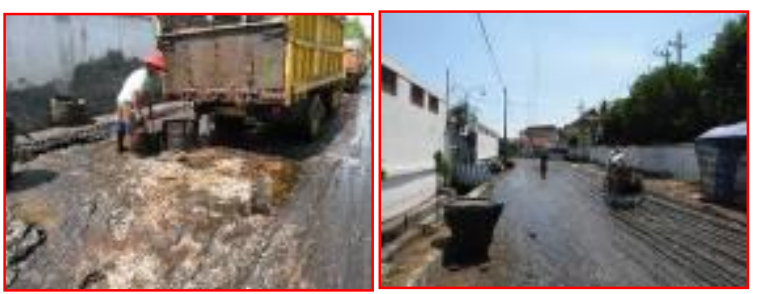

Foto 13. Kondisi Jalanan Yang Becek Akibat Sistem Tranportasi Yang Kurang Baik
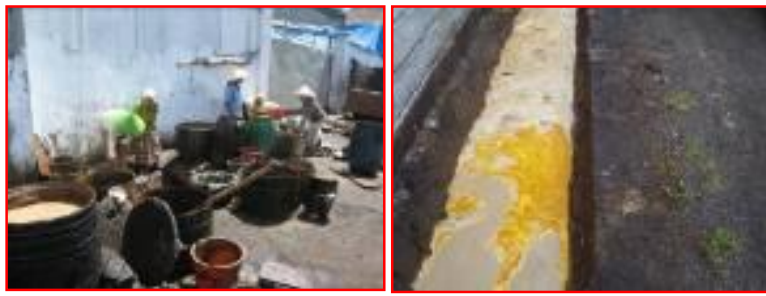

Foto 14. Kondisi Kondisi Saluran Yang Penuh Dengan Minyak Dan Aktivitas Masyarakat Pengais Minyak

\section{KESIMPULAN} yaitu:

Beberapa kesimpulan yang diperoleh

1. Potensi hasil limbah di Muncar sangat besar, sementara sarana yang tersedia untuk pengelolaan limbah sangat minim baik di tingkat industri maupun di tingkat kawasan.

2. Hampir semua industri pengolahan ikan di Muncar belum memiliki unit pengolahan limbah yang memenuhi persyaratan dan membuang limbah cair secara langsung tanpa unit pengolahan, walaupun ada industri yang telah memiliki unit pengolahan tetapi tidak berfungsi.

3. Seluruh industri pengolahan ikan diwajibkan melengkapi dengan Instalasi Pengolahan Air Limbah (IPAL).

4. Lokasi industri yang menyebar di seluruh kawasan Muncar menyebabkan limbah yang timbul juga menyebar di seluruh kawasan industri dan menyebabkan semakin sulitnya melakukan pengelolaan limbah di kawasan ini.

5. Diperlukan terobosan-terobosan agar dapat meminimalkan jumlah limbah maupun kadar polutan yang ada, antara lain dengan pengembangan proses produksi bersih (nir limbah), minimisasi limbah, penggantian bahan berbahaya dan dengan teknologi pengolahan limbah (end of pipe). Diperlukan teknologi pengolahan limbah agar dapat memberikan hasil pengelolaan yang optimal.

6. Dari segi penataan ruang, perlu dilakukan monitoring dan evaluasi terhadap RDTRK Muncar Tahun 1991/1992-2013/2014, dalam rangka peningkatan tata ruang kota dan pemanfaatan lahan kawasan muncar agar lebih terencana, terarah dan terpadu.

7. Dari segi kelestarian lingkungan, perlu ditingkatkan kepedulian serta bagaimana kesadaran pengusaha, masyarakat, dan tokoh masyarakat terhadap pengendalian pencemaran lingkungan.

8. Diperlukan perbaikan sistem sanitasi lingkungan.

9. Perlu penegakan hukum yang tegas terhadap pelanggaran pencemaran lingkungan sesuai peraturan perundangan yang berlaku.

\section{DAFTAR PUSTAKA}

1. Kedeputian Bidang Pengendalian Pencemaran Lingkungan, KLH, "Laporan Akhir Pengelolaan Lingkungan Industri Pengolahan Ikan di Muncar, Banyuwangi," tahun 2007.

2. Bappeda, Kab. Banyuwangi, "Pencemaran Lingkungan di Kecamatan Muncar" Disampaikan Pada: Rapat Koordinasi Pencemaran Lingkungan Bagi Industri Pengolahan Hasil Ikan di Kawasan Muncar, Muncar, Tahun 2007.

3. Peraturan Menteri Lingkungan Hidup. No. 06 tahun 2007, tentang Baku Mutu Air Limbah Bagi Usaha dan atau Kegiatan Pengolahan Hasil Perikanan.

4. Raka, I G., Zen, M.T., Soemarwoto, O., Djajadiningrat, S.T., and Saidi, Z. (1999). Paradigma Produksi Bersih: mendamaikan pembangunan ekonomi dan pelestarian lingkungan. Penerbit Nuansa, Bandung, Indonesia

5. - (1977). Fate of Pollutants in the Air and Water Environments. Volume 8. Part 2, "Chemical and biological fate of pollutants in the environment". Advances in Environmental Science and Technology. John Wiley \& Sons, A Wiley-Interscience Publications, New York, . 


\section{LAMPIRAN}

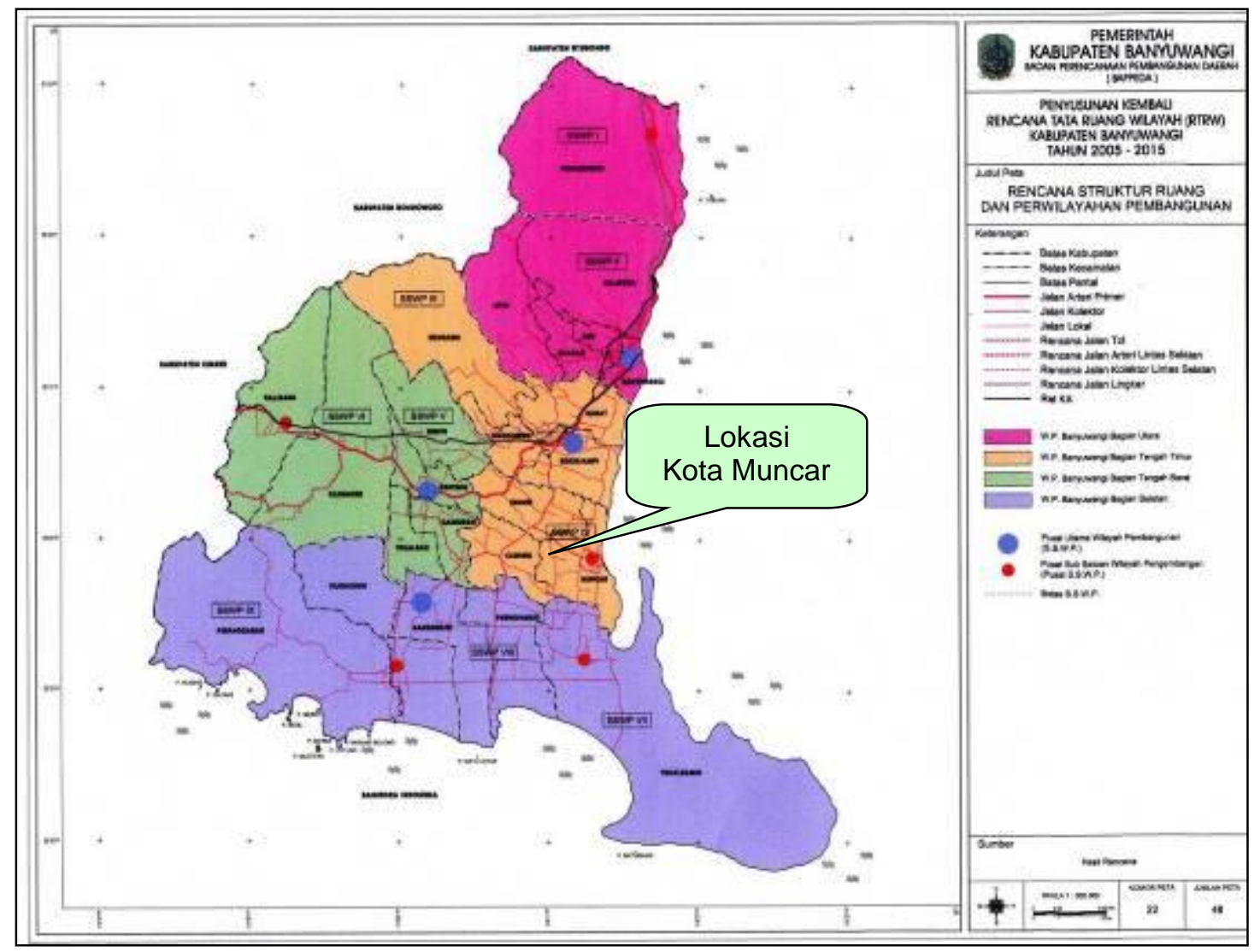

Gambar 2. Peta Lokasi Kota Muncar Dalam Wilayah Kabupaten Banyuwangi

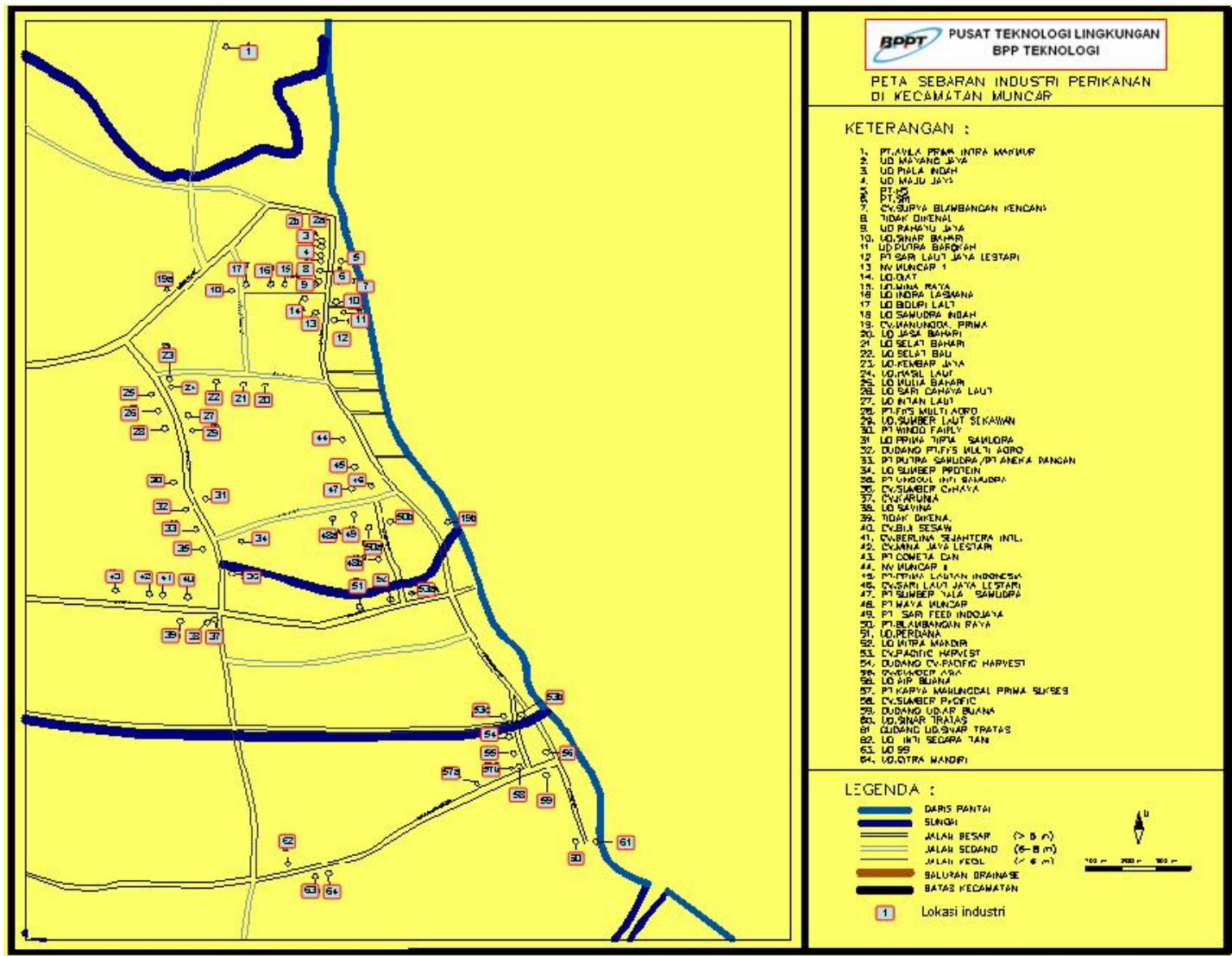

Gambar 3. Peta Sebaran Industri Pengolahan Ikan Di Muncar 


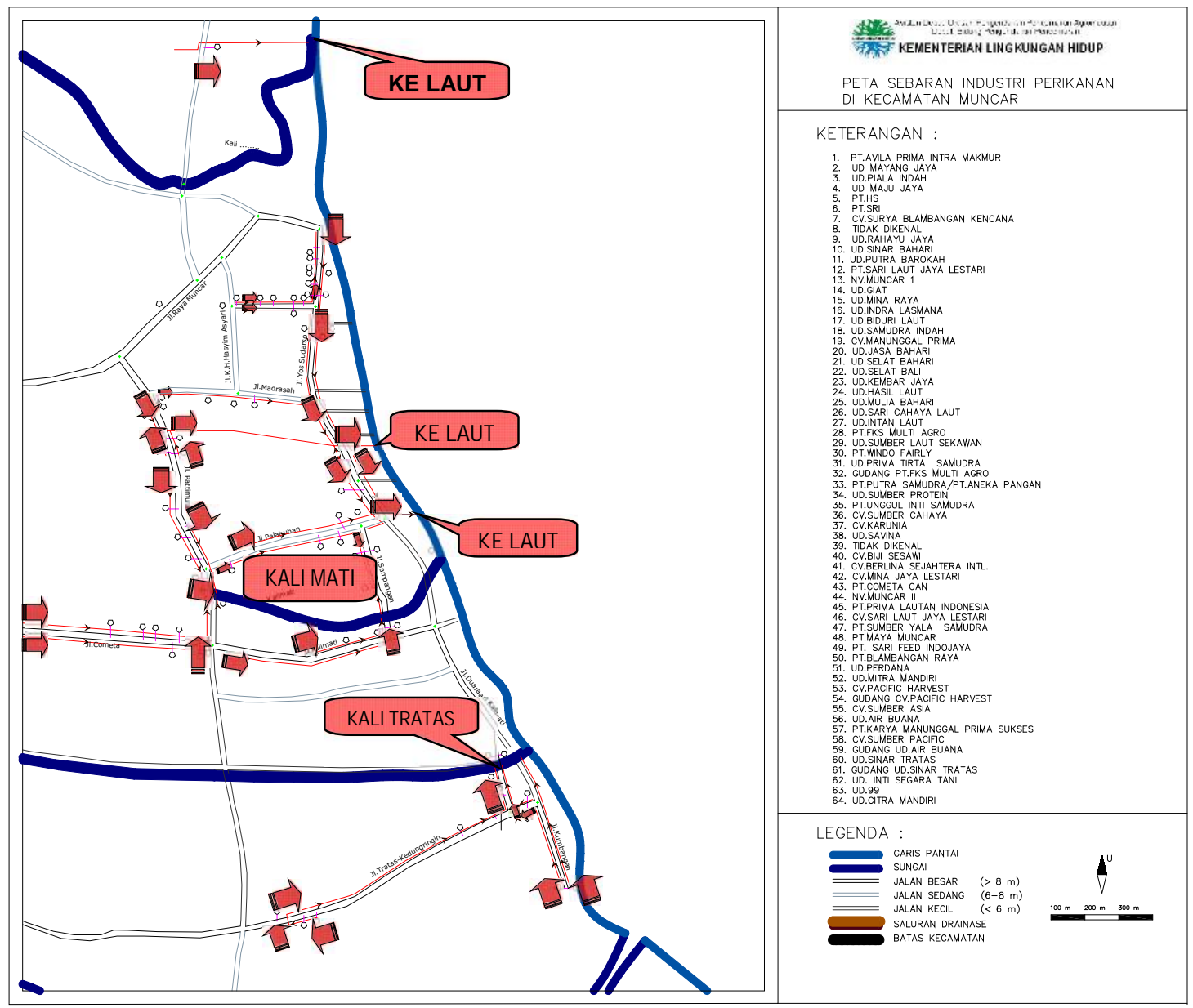

Gambar 4. Peta Sebaran Pembuangan Limbah Di Kawasan Muncar 